\title{
ADOBE CAPTIVATE - THE TOOL FOR THE INTERACTIVE E-LEARNING MATERIAL CREATION
}

\author{
Iveta ŽOUŽELKOVÁ - Zdenka PROKOPOVÁ
}

\section{ADOBE CAPTIVATE - NÁSTROJ PRO TVORBU INTERAKTIVNÍCH E-LEARNINGOVÝCH MATERIÁLŮ}

\author{
(Adobe Captivate 4)
}

\section{1 Úvod}

Moderní formy výuky si žádají maximální využití interaktivních multimediálních studijních materiálů. V lednu roku 2009 představila společnost Adobe Systems nový softwarový nástroj pro tvorbu e-learningového obsahu - CAPTIVE 4. Jedná se o nástupce programů Macromedia Captivate a RoboDemo, který snoubí bohatou funkčnost s přehledným a př́ijemným uživatelským rozhraním.

\section{Vlastnosti Adobe Captivate}

Adobe Captivate umožní i méně zkušeným uživatelům vytvořit velmi poutavý multimediální obsah. Bez znalosti programování nebo multimédií snadno docílíte velmi profesionálního výstupu, at' už se jedná o softwarové simulace, testy znalostí studentů, firemní prezentace, nebo jiné grafické výstupy vzniklé jejich kombinováním.

Aplikace pracuje na principu vytváření slajdů (snímků) podobně, jako známe z programu Microsoft PowerPoint (programy mohou mezi sebou dokonce sdílet obsah). Jejich vzájemné propojení určuje tzv. scénář, který umožňuje snímky větvit, spojovat do skupin, nebo přeskakovat, a tak docílit i velmi komplikované vnitřní struktury.

Každý slajd pak v rámci editačního módu upravujeme a „oživujeme“ tlačítky, obrázky, popiskami, audio záznamy (hudba, komentáŕ), dalšími videosekvencemi a animacemi. Právě záznam mluveného slova umožní lepší pochopení zmiňované problematiky a zpř́ístupní obsah i handicapovaným studentům. Audio lze nahrávat i editovat prímo v programu, takže není potřeba instalovat další softwarový nástroj pro záznam zvuku.

V rámci každého snímku je také časová osa (Time Line), na které jsou umístěny veškeré prvky a aplikované vizuální a zvukové efekty. Integrovaný player umožňuje přehrávání celého projektu nebo jen jeho částí už během editace, což usnadňuje tvorbu celkového konceptu.

Výstupní video využívá Flash technologie, a to ve dvou formátech: Flash Video (FLV) a ShockWave (SWF). Jeho přehrávání tedy vyžaduje instalaci Adobe Flash Playeru. Dále se nabízí i export do Audio Video Interleave (AVI) nebo do dokumentu MS Word.

Adobe Captivate je navíc plně kompatibilní se systémy pro řízení výuky, protože generovaný obsah odpovídá standardům SCORM 2004 a SCORM 1.2, stejně jako AICC, včetně nové specifikace PENS (Package Exchange Notification System).

\section{Aplikační možnosti}

Při spuštění programu se nabízí několik variant projektu podle jeho budoucího účelu. V následujících odstavcích se zaměříme na nejčastější z nich - softwarovou simulaci a testovací rozhraní.

Softwarová simulace patř́ mezi velmi žádané studijní pomůcky. Aplikace nabízí hned několik způsobů jak ji realizovat. Kromě klasického demonstračního videa, můžeme vytvářet i tutoriály a motivovat studenty aby zobrazený postup zopakovali.

Při záznamu předváděné aplikace Adobe Captivate provádí snímkování obrazovky (tzv. PrintScreen), pokaždé kdy dojde ke změně vizuálního výstupu. Pokud tedy např. rozbalíme položku v menu, bude vytvořen nový snímek a vložen jako pozadí do slajdů v Adobe Captivate.

Rozměr videa je bud' přizpůsoben snímanému oknu, nebo může být definován uživatelem a okno zaznamenávaného programu se poté prenastaví na zvolenou velikost. Program umožňuje i snímání celé obrazovky a přepínání mezi okny.

Pohyby myší jsou zaznamenány vektorově, tzn. pouze pomocí souřadnic výchozího 
a konečného bodu. Dráha kurzoru je poté generována automaticky. Podobným způsobem probíhá ukládání textu. Výhodou tohoto postupu je možnost dodatečné úpravy pohybu kurzoru, nastavení rychlosti, tvaru pointeru a trajektorie. Každé kliknutí a stisk klávesy je doprovázen zvukovým znamením popř. popiskou, což zlepšuje orientaci studentů v předváděné problematice. Výsledné video je velmi datově úsporné a jeho publikace na internetu se př́mo nabízí.

Interaktivní testy mohou sloužit $\mathrm{k}$ ověření získaných vědomostí. Pomocí průvodce snadno vložíme otázku. Program nabízí široký výběr typů (Multiple Choice, True/False, Fill-in-theblank, Matching a další) a také řadu dalších nastavení jako např. časové omezení pro jednotlivé otázky, chování programu po správném/nesprávném zodpovězení, náhodné generování otázek, celkové vyhodnocení testu atd.

Pro začínající uživatele je připraveno několik základních předloh projektů, které jim pomohou vytvořit požadovaný výstup téměř na první pokus. Pro seznámení s možnostmi programu Adobe Captivate slouží tutoriály, které lze vnímat současně jako návody a ukázky toho, co program nabízí.

\section{Technické požadavky}

Adobe Captivate je vytvořen pro operační systémy společnosti Microsoft Windows XP (min. Service Pack 2) a Vista (Service Pack 1 - 32bitová edice).

Hardwarové požadavky udávané firmou Adobe specifikují PC sestavu, která by měla zajistit bezproblémový chod aplikace. Doporučenými procesory jsou Intel Pentium 4, Intel Centrino, Intel Xeon nebo Intel Core ${ }^{\mathrm{TM}}$ Duo (nebo kompatibilní). Výrobce navrhuje alespoň $512 \mathrm{MB}$ operační paměti a nejméně $1,5 \mathrm{~GB}$ místa na disku. Dále doporučuje nastavit rozlišení obrazovky výše než $800 x 600$. Počítač by také měl obsahovat DVD-ROM mechaniku.

\section{Závěr}

Mezi největší přednosti programu Adobe Captivate patří jednoduché a intuitivní ovládání, které zpř́stupní i méně zkušeným uživatelům tvorbu velmi poutavého multimediálního obsahu. Snímání obrazovky netvoří pouze holé video, ale umožňuje i následnou editaci, jejíž nástroje jsou skutečně bohaté. Jednoduchá tvorba testů, prezentací a programových simulací dělá z Adobe Captivate silný e-learningový nástroj.
Jeho využití lze vidět nejen ve školství, ale i ve firmách zabývajících se vývojem softwaru a následným školením svých zákazníků.

Negativ není mnoho. Za zmínku snad stojí jen absence české lokalizace. Využití Flash technologie je moderní a $\mathrm{v}$ dnešní době běžné, ale přesto je uživatel nucen instalovat další podpůrný software - Adobe Flash Player. Pokud ale překonáte tuto drobnou komplikaci, získáte nástroj, který svou funkčností jistě uspokojí i náročnější uživatele.

\section{Literatura}

[1] Adobe Systems Incorporated. Adobe Captivate 4 [online]. c2009 [cit. 2009-12-20]. Dostupný z WWW: <http://www.adobe.com/cz/ products/captivate/>.

[2] Software Amos: Adobe Captivate 4 [online]. c2008 [cit. 2010-01-12]. Dostupný z WWW: $<$ http://www.techsoft.cz/produkty/adobe/captivat e/overview.html>.

[3] BAŇAROVÁ, Jitka. Adobe Captivate jako multimediální nástroj a jeho využívání na Ekonomické fakultě, VŠB-TU Ostrava [online]. 2008 [cit. 2010-01-12]. Dostupný z WWW: $<$ http://handicap.vsb.cz/wiki/images/a/a7/Jitka_B anarova_SMM.pdf $>$.

[4] Wikipedia : Adobe Captivate [online]. 2009 [cit. 2010-01-10]. Dostupný z WWW: $<$ http://en.wikipedia.org/wiki/Adobe_Captivate>.

[5] BRICHTA, Ondřej. Recenze Macromedia Captivate - pomocník při výuce počítačových programů. Živě : Computer [online]. 2005 [cit. 2010-01-10]. Dostupný z WWW: <http://www. zive.cz/Clanky/Recenze-Macromedia-Captivate--pomocnik-pri-vyuce-pocitacovych-programu/sc3-a-124410/default.aspx>.

[6] ARAH, Tom. Adobe Captivate 4. PCPRO [online]. 2009 [cit. 2010-01-12]. Dostupný z WWW: $<$ http://www.pcpro.co.uk/reviews/ software/248213/adobe-captivate-4>.

\section{Ing. Iveta Žouželková \\ doc. Ing. Zdenka Prokopová, CSc. \\ Ústav aplikované informatiky \\ Fakulta aplikované informatiky \\ Univerzita Tomáše Bati ve Zlíně \\ Nad Stráněmi 4511, \\ 76005 Zlín, \\ Česká republika \\ telefon: +420 57-603-5196 \\ E-mail: zouzelkova@fai.utb.cz, prokopova@fai.utb.cz \\ Www pracoviště: www.fai.utb.cz}

